\title{
Genetic Polymorphisms of the Human Cytochrome P450 1A1 (CYP1A1) and Cervical Cancer Susceptibility among Northeast Thai Women
}

\author{
Mayuree Wongpratate ${ }^{1}$, Wannapa Settheetham-Ishida ${ }^{1 *}$, Sophida Phuthong ${ }^{1}$, \\ Sitakan Natphopsuk ${ }^{2}$, Takafumi Ishida ${ }^{3}$
}

\begin{abstract}
Background: CYP1A1 is an enzyme in phase I of the cytochrome P450 (CYP) superfamily, and plays a key role in detoxification of carcinogens. Host genetic predisposition in the CYP1A1 may be associated with an increased susceptibility to cervical cancer. The study aimed to evaluate four common polymorphisms of the CYP1A1 and cervical cancer susceptibility among Northeast Thai women. Methods: A case-control study was conducted involving 204 patients with squamous cell cervical cancer (SCCA) and 204 age-matched healthy controls. DNA was extracted from peripheral blood leucocytes. CYP1A1 $\mathrm{m} 1, \mathrm{~m} 3$, and $\mathrm{m} 4$ genotypes were detected using PCR-RFLP, whereas the CYP1A1 $\mathrm{m} 2$ genotype was investigated using real-time PCR. Haplotype analysis was performed using PHASE algorithm version 2.1.1. Results: $C Y P 1 A 1 \mathrm{~m} 3$ was monomorphic. Association between the common $C Y P 1 A 1$ polymorphisms, $\mathrm{m} 1$ and $\mathrm{m} 2$, and cervical cancer risk was not observed $(p>0.05)$, nor was any association found between the $\mathrm{m} 1-\mathrm{m} 2-\mathrm{m} 4$ haplotype and cervical cancer risk ( $p>0.05$ ). Interestingly, the CA genotype of CYP1A1 m4 was observed in $30.88 \%$ of the cervical cancer patients but was absent in healthy controls. Conclusion: Our results demonstrated a possible involvement of the CYP1A1 $\mathrm{m} 4$ polymorphism but no other common polymorphisms (viz., $\mathrm{m} 1, \mathrm{~m} 2$, and $\mathrm{m} 3$ ) in the risk for cervical cancer.This finding may be useful when screening for risk of cervical cancer among Northeast Thai women.
\end{abstract}

Keywords: Genetic polymorphisms- CYP1A1- cervical cancer- risk

Asian Pac J Cancer Prev, 21 (1), 243-248

\section{Introduction}

Cytochrome P450 1A1 (CYP1A1), an important enzyme in phase I of cytochrome P450 superfamily (CYPs), plays a key role in the detoxification of several xenobiotics (e.g., 7-ethoxyresorufin, theophylline, caffeine, and 7-ethoxycoumarin) and endogenous substances (e.g., $17 \beta$-estradiol and estrone) (Bozina et al., 2009). In addition to these substances, CYP1A1 has potential for catalyzing environmental procarcinogens such as polycyclic aromatic hydrocarbons (PAHs), leading to generation of reactive metabolites that are highly reactive towards DNA (Androutsopoulos et al., 2009). Accumulating evidence shows that CYP1A1 polymorphisms are associated with an increased susceptibility to cancer (Bartsch et al., 2000; Bozina et al., 2009; Androutsopoulos et al., 2009); due to alterations to mRNA expression and enzymatic activity (Cosma et al., 1993; Crofts et al., 1994, and Schwarz et al., 2001). These changes may influence the balance between electrophilic molecules and reactive metabolites, leading to DNA adduct formation and the initiation of carcinogenesis (Attia, 2010).

Comprising seven exons and six introns, the CYP1A1 is located on 15q22-24 (Masson et al., 2005). It is generally expressed in extrahepatic tissues, especially epithelial tissues (Bozina et al., 2009; Santes-Palacios et al., 2016). Among CYP1A1 variant alleles, common variants include four single nucleotide polymorphisms (SNPs): T3801C (m1), A2455G (m2), T3205C (m3), and C2453A (m4) (Bozina et al., 2009). Ordinary, $\mathrm{m} 1$ and $\mathrm{m} 3$ are located in the 3 ' noncoding region, giving rise to a $M s p I$ restriction site; whereas $\mathrm{m} 2$ and $\mathrm{m} 4$ are located in exon 7 , leading to the amino acid transition of isoleucine to valine on codon 462 and threonine to asparagine on codon 461, respectively (Li et al., 2004). To date, genetic polymorphisms of human $C Y P 1 A 1$ have been widely studied for the susceptibility to various cancers (e.g., cancer of lung, oral, larynx, breast, thyroid, prostate, renal, cervix uteri, gastric, and colon) (Li et al., 2004; Gajecka et al., 2005; Little et al., 2006; Siraj et al., 2008; Wright et al.,

${ }^{1}$ Department of Physiology, Faculty of Medicine, Khon Kaen University, Khon Kaen, ${ }^{2}$ Chulabhorn International College of Medicine, Thammasat University, Thailand, ${ }^{3}$ Unit of Human Biology and Genetics, Department of Biological Sciences, Graduate School of Science, University of Tokyo, Tokyo, Japan.*For Correspondence: wannapa@kku.ac.th 
2010; Li et al., 2016; Balaji et al., 2012; Agudo et al., 2014; Meng et al., 2015). Notwithstanding, to our knowledge there are no recent reports of any association between the four polymorphic loci of the CYP1A1 and cervical cancer susceptibility (Sugawara et al., 2003; Juárez-Cedillo et al., 2007; Gutman et al., 2009; Roszak et al., 2014; Abbas et al., 2014; Tan et al., 2016; Jain et al., 2017). Our aim was thus to evaluate these four polymorphic loci of CYP1A1 for the cervical cancer susceptibility among Northeast Thai women.

\section{Materials and Methods}

\section{Subjects}

This was a case-control study, including 408 female volunteers between 26 and 81 years of age-conducted at Srinagarind Hospital and KhonKaen Hospital in KhonKaen Province, Northeast Thailand, between February 2009 and August 2011. The subjects included 204 cases of pathologically-defined squamous cell carcinoma of the cervix and 204 age-matched healthy women (5-year intervals) confirmed by cytological and histological examination. The sample size was obtained from the case-control sample size table where the level of significance, $\alpha=0.05$; the power $=0.9 ; \beta=0.2$; relative risk, $\mathrm{R}=3.0$; and proportion of mutant type, $\mathrm{P}_{0}=0.05$ (Schlesselman, 1982). Each subject was informed of the methodology and objectives of the research and signed an informed consent form. The study was reviewed and approved by the Ethics Committee of KhonKaen University (HE 571482).

\section{Detection of CYP1A1 polymorphisms}

Three milliliters of EDTA-blood samples were collected from all subjects. The genomic DNA was extracted from the buffy coat using GF-1 Blood DNA Extraction Kits (Vivantis, USA). Four polymorphisms (m1, m2, m3, and $\mathrm{m} 4)$ of the CYP1A1 were analyzed. The $\mathrm{m} 1, \mathrm{~m} 3$, and $\mathrm{m} 4$ SNPs were examined using the polymerase chain reaction restriction fragment length polymorphism (PCR-RFLP) method (C1000TM Thermal Cycler 96W SYS, Bio-Rad, USA), while the m2 SNP was examined using TaqMan probe real-time PCR method (7500 Fast Real-Time PCR System, Applied Biosystems, USA).

The PCR condition and PCR reaction mixture are as follow

$m 2, m 3, m 4$ SNP detection - The method and sequence of primer pairs follow Hussein et al., (2014). The PCR reaction mixture contained $12.5 \mu \mathrm{L}$ of $2 \mathrm{X}$ Taq Master Mix, $0.2 \mu \mathrm{L}$ of each primer, $11.1 \mu \mathrm{L}$ of distilled water, and 1 $\mu \mathrm{L}$ of genomic DNA $(80 \mathrm{ng} / \mu \mathrm{L})$, reaching a final volume of $25 \mu \mathrm{L}$. The following condition was used to amplify: a holding stage at $95^{\circ} \mathrm{C}$ for 9 minutes, followed by 35 cycles of denaturation at $94^{\circ} \mathrm{C}$ for 60 seconds, annealing at $57^{\circ} \mathrm{C}$ for 45 seconds, and extension at $72^{\circ} \mathrm{C}$ for 45 seconds, and the final elongation step at $72^{\circ} \mathrm{C}$ for 4 minutes. The PCR product was digested using the MspI enzyme (New England, USA) in 1 UL of 10x NE buffer (New England. USA), incubated at $37^{\circ} \mathrm{C}$ for 2 hours confirmed by $2 \%$ agarose gel electrophoresis, followed by ethidium bromide staining, and photographed under UV light.

\section{m2 SNP detection}

The PCR reaction of $10 \mu \mathrm{L}$ included $5 \mu \mathrm{L}$ of TaqMan Universal PCR Master Mix, $0.5 \mu \mathrm{L}$ of TaqMan probe with primers, $3.5 \mathrm{uL}$ of distilled water, and $1 \mu \mathrm{L}$ of genomic DNA. The holding stage was at $95^{\circ} \mathrm{C}$ for 10 minutes, followed by 40 cycles of denaturation at $95^{\circ} \mathrm{C}$ for 15 seconds, annealing at $60^{\circ} \mathrm{C}$ for 60 seconds, and extension at $60^{\circ} \mathrm{C}$ for 60 seconds. The TaqMan ${ }^{\circledR}$ probe with primers (Applied Biosystems, USA) was designed for a specific SNP (viz., SNP assay: C_25624888_50). The respective FAM and VIC fluorescence dyes on the probes were used for the wild type (A allele) and the mutant type ( $\mathrm{G}$ allele) (Balaji et al., 2012).

\section{m3 SNP detection}

The method and sequence of primer pairs followed Hirata et al., (2008). The PCR reaction mixture contained 12.5 $\mu \mathrm{L}$ of $2 \mathrm{X}$ Taq Master Mix, $0.2 \mu \mathrm{L}$ of each primer, 9.1 $\mu \mathrm{L}$ of distilled water, and $3 \mu \mathrm{L}$ of genomic DNA, reaching a final volume of $25 \mu \mathrm{L}$. The holding stage was at $94^{\circ} \mathrm{C}$ for 9 minutes, followed by 35 cycles of denaturation at $94^{\circ} \mathrm{C}$ for 30 seconds, annealing at $54^{\circ} \mathrm{C}$ for 40 seconds, and extension at $72^{\circ} \mathrm{C}$ for 40 seconds, with the final elongation step at $72^{\circ} \mathrm{C}$ for 4 minutes. The MspI enzyme (New England, USA) was used to distinguish the $\mathrm{m} 3$ genotype, incubated at $37^{\circ} \mathrm{C}$ for 2 hours and confirmed by $2 \%$ agarose gel electrophoresis with GelRed (DNA dye-ViSafe Red Gel Stain, Vivantis, USA).

\section{m4 SNP detection}

The method and sequence of primer pairs followed Cascorbi et al., (1996). The PCR reaction mixture contained $12.5 \mu \mathrm{L}$ of $2 \mathrm{X}$ Taq Master Mix, $0.5 \mu \mathrm{L}$ of each primer, $9.5 \mu \mathrm{L}$ of distilled water, and $2 \mu \mathrm{L}$ of genomic DNA, reaching a final volume of $25 \mu \mathrm{L}$. The holding stage was at $94^{\circ} \mathrm{C}$ for 5 minutes, followed by 35 cycles of denaturation at $94^{\circ} \mathrm{C}$ for 30 seconds, annealing at $61^{\circ} \mathrm{C}$ for 30 seconds, and extension at $72^{\circ} \mathrm{C}$ for 30 seconds, with a final elongation step at $72^{\circ} \mathrm{C}$ for 4 minutes. The $B s a \mathrm{I}$ enzyme (New England, USA) was used to distinguish the $\mathrm{m} 4$ genotype, incubated at $37^{\circ} \mathrm{C}$ for 4 hours, and confirmed by $2.5 \%$ agarose gel electrophoresis with GelRed (DNA dye-ViSafe Red Gel Stain, Vivantis, USA).

\section{Statistical analyses}

Statistical analyses were performed using STATA software V.14. The association between each SNP of the CYP1A1 polymorphisms and cervical cancer risk was assessed using uni- then multivariate logistic regression. The Hardy-Weinberg equilibrium was tested using Pearson's chi-square. The haplotype analysis of the CYP1A1 was performed using PHASE algorithm version 2.1.1. The strength of association between the CYP1A1 polymorphisms and cervical cancer risk was measured using odds ratios (ORs) with $95 \%$ confidence intervals (CIs). A $p$-values of $<0.05$ was considered as statistically significant. 


\section{Results}

Genotype distributions and allele frequencies of the four loci of the CYP1A1 are summarized in Table 1. One locus, CYP1A1 m3, was monomorphic. The A allele of $\mathrm{m} 4$ was detected only in the cases $(C A=63 / 204$ cases, $30.88 \%$ ) but the AA genotype was not detected (Figure 1). No association was found between the $\mathrm{m} 1, \mathrm{~m} 2$, and $\mathrm{m} 4$ genotypes and cervical cancer risk $(p>0.05)$. The genotype distributions of the $\mathrm{m} 1$ and $\mathrm{m} 2$ polymorphisms among the controls and cases were consistent with the Hardy-Weinberg equilibrium (HWE) $(p>0.05)$; however, that of the $\mathrm{m} 4$ polymorphism among the cases deviated from the HWE $(p<0.01)$. The presence of the A allele carrying chromosomes being only among the cases was an unexpected finding (Fisher's exact test $p<0.0001$ ). We then evaluated the characteristics of the $\mathrm{m} 4$ A allele carriers. Among the 204 cases, the A allele carriers did not show (a) age dependency, (b) different HPV positivity, or (c) difference in age of menarche.

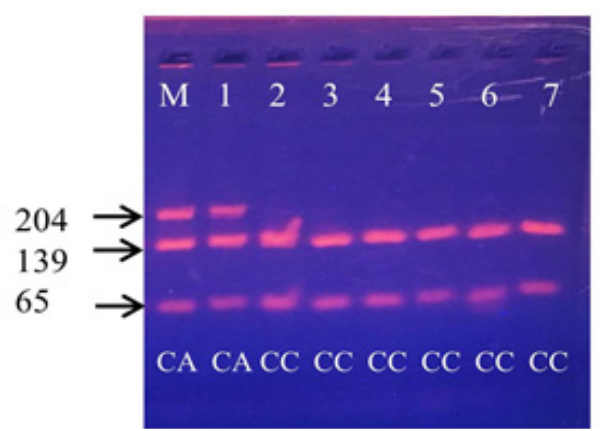

Figure 1. Example of Restriction Fragment Length Polymorphism (RFLP) of CYP1A1 m4 Products: BsaI enzyme was used to digest the 204-bp product of CYP1A1 m4, $\mathrm{M}$ is a molecular-weight size marker, the homozygous wild-type (CC) produced two bands, a 139-bp and 65-bp as shown in lanes 2, 3, 4, 5, 6 and 7 , the heterozygous type (CA) produced three bands, a 204-bp, 139-bp and 65-bp as shown in lanes $\mathrm{M}$ and 1 and the homozygous mutant-type (AA) produced entirely 204-bp which was not detected in this study.

Table 1. CYP1A1 m1, m2, m3 and m4 Polymorphisms and Cervical Cancer Risk

\begin{tabular}{|c|c|c|c|c|c|}
\hline Polymorphisms & Genotypes (Allele) & Cases n (\%) & Controls n $(\%)$ & $\begin{array}{c}\text { Crude OR } \\
{[95 \% \text { CI, } p]}\end{array}$ & $\begin{array}{c}\text { Adjusted OR }{ }^{\mathrm{a}} \\
{[95 \% \mathrm{CI}, p]}\end{array}$ \\
\hline \multirow{6}{*}{$\begin{array}{l}\mathrm{m} 1 \\
\text { T3801C } \\
\text { Intron }\end{array}$} & TT & $\begin{array}{c}46 \\
(22.55)\end{array}$ & $\begin{array}{c}52 \\
(25.49)\end{array}$ & 1 & 1 \\
\hline & $\mathrm{TC}$ & $\begin{array}{c}104 \\
(50.98)\end{array}$ & $\begin{array}{c}100 \\
(49.02)\end{array}$ & $\begin{array}{c}1.18 \\
{[0.70-1.96,0.5107]}\end{array}$ & $\begin{array}{c}1.51 \\
{[0.74-3.08,0.262]}\end{array}$ \\
\hline & $\mathrm{CC}$ & $\begin{array}{c}54 \\
(26.47)\end{array}$ & $\begin{array}{c}52 \\
(25.49)\end{array}$ & $\begin{array}{c}1.17 \\
{[0.65-2.11,0.5676]}\end{array}$ & $\begin{array}{c}1.98 \\
{[0.87-4.48,0.103]}\end{array}$ \\
\hline & $\mathrm{TC}+\mathrm{CC}$ & $\begin{array}{c}158 \\
(77.45)\end{array}$ & $\begin{array}{c}152 \\
(74.51)\end{array}$ & $\begin{array}{c}1.18 \\
{[0.73-1.90,0.4869]}\end{array}$ & $\begin{array}{c}1.65 \\
{[0.84-3.24,0.147]}\end{array}$ \\
\hline & $(\mathrm{T})$ & 0.48 & 0.5 & 1 & NA \\
\hline & (C) & 0.52 & 0.5 & $\begin{array}{c}1.084 \\
{[0.82-1.43,0.5695]}\end{array}$ & NA \\
\hline \multirow{6}{*}{$\begin{array}{l}\mathrm{m} 2 \\
\mathrm{~A} 2455 \mathrm{G} \\
\text { Ile462 Val } \\
\text { Exon } 7\end{array}$} & AA & $\begin{array}{c}96 \\
(47.06)\end{array}$ & $\begin{array}{c}99 \\
(48.53)\end{array}$ & 1 & 1 \\
\hline & $A G$ & $\begin{array}{c}90 \\
(44.12)\end{array}$ & $\begin{array}{c}90 \\
(44.12)\end{array}$ & $\begin{array}{c}1.03 \\
{[0.67-1.58,0.8817]}\end{array}$ & $\begin{array}{c}1.04 \\
{[0.57-1.80,0.899]}\end{array}$ \\
\hline & GG & $\begin{array}{c}18 \\
(8.82)\end{array}$ & $\begin{array}{c}15 \\
(7.35)\end{array}$ & $\begin{array}{c}1.24 \\
{[0.55-2.80,0.5723]}\end{array}$ & $\begin{array}{c}2.54 \\
{[0.88-7.35,0.085]}\end{array}$ \\
\hline & $\mathrm{AG}+\mathrm{GG}$ & $\begin{array}{c}108 \\
(52.94)\end{array}$ & $\begin{array}{c}105 \\
(51.47)\end{array}$ & $\begin{array}{c}1.06 \\
{[0.70-1.59,0.7662]}\end{array}$ & $\begin{array}{c}1.19 \\
{[0.67-2.09,0.550]}\end{array}$ \\
\hline & (A) & 0.691 & 0.706 & 1 & NA \\
\hline & (G) & 0.309 & 0.294 & $\begin{array}{c}1.074 \\
{[0.79-1.46,0.6427]}\end{array}$ & NA \\
\hline m3, T3205C, Intron & TT & $\begin{array}{c}204 \\
(100)\end{array}$ & $\begin{array}{c}204 \\
(100)\end{array}$ & 1 & 1 \\
\hline \multirow{5}{*}{$\begin{array}{l}\mathrm{m} 4 \\
\text { C2453A } \\
\text { Thr461Asp } \\
\text { Exon7 }\end{array}$} & $\mathrm{CC}$ & $\begin{array}{c}141 \\
(69.12)\end{array}$ & $\begin{array}{l}204 \\
(100)\end{array}$ & 1 & 1 \\
\hline & $\mathrm{CA}$ & $\begin{array}{c}63 \\
(30.88)\end{array}$ & $\begin{array}{c}0 \\
(0.00)\end{array}$ & b & - b \\
\hline & AA & $\begin{array}{c}0 \\
(0.00)\end{array}$ & $\begin{array}{c}0 \\
(0.00)\end{array}$ & b & -b \\
\hline & (C) & 0.85 & 1 & 1 & NA \\
\hline & (A) & 0.15 & 0 & $b$ & NA \\
\hline
\end{tabular}

NA, not applicable; OR, odds ratio; CI, confidence interval; adjusted multiple logistic regression for contraceptive use, partner smokes, and HPV infection; ${ }^{\mathrm{b}}$, drop because of a zero cell count 
Table 2. CYP1A1 m1-m2-m4 Haplotype and Cervical Cancer Risk

\begin{tabular}{|c|c|c|c|}
\hline CYP1A1 haplotypes (m1-m2-m4) & Cases n $(\%)$ & Controls n $(\%)$ & $\mathrm{OR}[95 \% \mathrm{CI}, p]$, T-A-C as reference \\
\hline $\mathrm{T}-\mathrm{A}-\mathrm{C}$ & $163(39.95)$ & $200(49.02)$ & 1 \\
\hline T-A-A & $33(8.09)$ & $0(0.00)$ & $\_b$ \\
\hline T-G-C & $0(0.00)$ & $4(0.98)$ & - b \\
\hline T-G-A & $0(0.00)$ & $0(0.00)$ & b \\
\hline $\mathrm{C}-\mathrm{A}-\mathrm{C}$ & $75(18.38)$ & $88(21.57)$ & $1.046[0.72-1.52,0.8132]$ \\
\hline C-A-A & $11(2.70)$ & $0(0.00)$ & b \\
\hline C-G-C & $106(25.98)$ & $116(28.43)$ & $1.121[0.80-1.57,0.5030]$ \\
\hline C-G-A & $20(4.90)$ & $0(0.00)$ & $b$ \\
\hline
\end{tabular}

OR, odds ratio; CI, confidence interval; ${ }^{b}$ drop because of a zero cell count

The haplotype analysis of CYP $1 A 1 \mathrm{~m} 1-\mathrm{m} 2-\mathrm{m} 4$ is shown in Table 2. Taking $\mathrm{T}-\mathrm{A}-\mathrm{C}$ as the reference, a relationship between the $\mathrm{m} 1-\mathrm{m} 2-\mathrm{m} 4$ haplotype and cervical cancer risk was not observed $(p>0.05)$.

\section{Discussion}

We evaluated the association between four common polymorphisms in the human CYP1A1 and development of cervical cancer among Northeastern Thai women. In this study, the $\mathrm{m} 3$ locus was monomorphic as in other reports for Indians (Singh et al., 2007) and Americans (San Francisco) (Hirata et al., 2008). The polymorphic status in the $\mathrm{m} 3$ locus may be specific for persons of African-American descent (Garte et al., 2001; Li et al., 2004). Our results show a lack of significant association between $\mathrm{m} 1$ and $\mathrm{m} 2$ polymorphisms and cervical cancer risk, which as in several others tudies-done among Japanese, Israeli Jewish, Polish, Chinese, and Indian populations (Sugawara et al., 2003; Gutman et al., 2009; Roszak et al., 2014; Tan et al., 2016). To contrast, significant associations between $\mathrm{m} 1$ and/or $\mathrm{m} 2$ polymorphism and increased cervical cancer risk have been documented in several populations (Tan et al., 2017; Juárez-Cedillo et al., 2007; Jain et al., 2017; Li et al., 2016; Wang et al., 2017; Ding et al., 2018), and a meta-analysis indicated that the $\mathrm{m} 1$ (CC) genotype was associated with an increased risk for cervical cancer among Asians and Mixed populations (Wu et al., 2013). It is thus premature to conclude the role of $\mathrm{m} 1$ and $\mathrm{m} 2$ polymorphisms in cervical cancer development.

No significant association was found between the $\mathrm{m} 1-\mathrm{m} 2-\mathrm{m} 4$ haplotypes and cervical cancer risk in the current study $(p>0.05)$. At present, only a few studies have reported an association between $C Y P 1 A 1$ haplotypes and cancer susceptibility. Wright et al.,(2010) and Shah et al., (2008) showed that when using the T-A-C haplotype as the reference, the $\mathrm{C}-\mathrm{G}-\mathrm{C}$ and $\mathrm{T}-\mathrm{G}-\mathrm{C}$ haplotypes were associated with an increased risk of lung cancer. To compare, Chang et al., (2003) showed that the C-A-C haplotype was associated with a decreased risk of prostate cancer via the role of estrogen metabolism. These inconsistent findings may indicate a specific role of the CYP1A1 haplotypes in different types of cancer.

As for $\mathrm{m} 4$ polymorphism, possible associations have been documented between the A allele and risk for lung cancer (Gallegos-Arreola et al., 2008; Shah et al., 2008;
Ezzeldin et al., 2017), laryngeal squamous cell carcinoma (Gajecka et al., 2005) and thyroid cancer (Siraj et al., 2008). No association has been observed between $\mathrm{m} 4$ polymorphism and breast, colorectal, and gastric cancer (Li et al., 2004; Singh et al., 2007; Amrani et al., 2016, Little et al., 2006; Agudo et al., 2014). Moreover, none of the previous studies have documented any association between $\mathrm{m} 4$ polymorphisms and cervical cancer; notwithstanding, our finding that the A allele existed only among cases $(p<0.0001)$ strongly suggests participation of the CYP1A1 m4 A allele in the development of cervical cancer. We attempted to determine the cause of the high concentration of the A allele among cases (at least 60 -fold over that of the controls, data not shown); by analyzing personal parameters. We then considered with respect to CYP1A1 function in the metabolic activation of carcinogens.

Benzo[a]pyrene-an environmental procarcinogen-is a specific substrate for CYP1A1 activation leading to generation of highly reactive intermediates-such as $\mathrm{B}[\mathrm{a}]$ P-7,8-diol-9,10-epoxide (BPDE), which is classified as the potent carcinogenic metabolite (Bozina et al., 2009; Androutsopoulos et al., 2009). BPDE-DNA adducts have been identified in human epithelial cervical tissue, especially among smokers (Melikian et al., 1999). In human tissues, CYP1A1 mRNA expression in the cervix is low (Hu et al., 2016); however, high up-regulation of the CYP1A1 mRNA, protein, and activity can be detected by inducers (e.g., polycyclic aromatic hydrocarbons) (Nebert et al., 2004). While CYP1A1 activity trends to be highest for the $\mathrm{m} 4$ variant in benzo[a]pyrene metabolism (Schwarz et al., 2001), the $\mathrm{m} 4$ variant exhibits the greatest catalytic efficiency for producing diol species and significantly increases formation of diol epoxide-2 (BPDE2) - the potent mutagenic species associated with increased cancer risk (Schwarz et al., 2001; Rubin, 2001). Smoking is a major risk factor for development of cervical cancer among Northeast Thai women (Natphopsuk et al., 2012). Although our smokers were passive smokers, those with the A allele may be more vulnerable to the carcinogenicity of smoke than those with the CC genotype. There is thus a possibility that the $\mathrm{m} 4$ variant of the A allele plays a key role in the development of cervical cancer.

In summary, our results demonstrated the possible involvement of the CYP1A1 $\mathrm{m} 4$ polymorphism over against other common polymorphisms $(\mathrm{m} 1, \mathrm{~m} 2$, and $\mathrm{m} 3)$ in the risk for cervical cancer among Northeast Thai women. 


\section{Acknowledgements}

This study was partly supported by (a) a Research Fund for Supporting Lecturer to Admit High Potential Student to Study and Research on Expert Program Year 2017 (601JH209), Graduate School, Khon Kaen University, (b) an Invitation Research Grant from the Faculty of Medicine, Khon Kaen University (IN62101), (c) research funds from KhonKaen University, and (d) the JSPS Core University Program. The authors thank (a) the staff and patients who took part in this study and the Publication Clinic, Research Affairs, Faculty of Medicine, Khon Kaen University, and (b) Mr. Bryan Roderick Hamman for assistance with the English-language presentation of the manuscript under the aegis of the Khon Kaen University Publication Clinic.

\section{References}

Abbas M, Srivastava K, Imran M, et al (2014). Association of CYP1A1 gene variants rs4646903 (T>C) and rs1048943 $(A>G)$ with cervical cancer in a North Indian population. Eur J Obstet Gynecol Reprod Biol, 176, 68-74.

Agudo A, Sala N, Pera G, et al (2006). Polymorphisms in metabolic genes related to tobacco smoke and the risk of gastric cancer in the European prospective investigation into cancer and nutrition. Cancer Epidemiol Biomarkers Prev, 15, 2427-34.

Amrani I, Bulatova N, Awidi A, et al (2016). Lack of association between CYP1A1 M2 and M4 polymorphisms and breast carcinoma in Jordanian Women: a case-control study. Asian Pac J Cancer Prev, 17, 387-93.

Androutsopoulos VP, Tsatsakis AM, Spandidos DA (2009). Cytochrome P450 CYP1A1: wider roles in cancer progression and prevention. BMC Cancer, 9, 187-203.

Attia SM (2010). Deleterious effects of reactive metabolites. Oxid Med Cell Longev, 3, 238-53.

Balaji L, Singh KB, Bhaskar LV (2012). CYP1A1 genotypes and haplotypes and risk of oral cancer: A case-control study in South Indians. Genet Mol Biol, 35, 407-12.

Bartsch H, Nair U, Risch A, et al (2000). Genetic polymorphism of CYP genes, alone or in combination, as a risk modifier of tobacco-related cancers. Cancer Epidemiol Biomarkers Prev, 9, 3-28.

Bozina N, Bradamante V, Lovrić M (2009). Genetic polymorphism of metabolic enzymes cancer risk. ArhHig Rada Toksikol, 60, 217-42.

Cascorbi I, Brockmöller J, Roots I (1996). A C4887A polymorphism in exon 7 of human CYP1A1: population frequency, mutation linkages, and impact on lung cancer susceptibility. Cancer Res, 56, 4965-9.

Chang BL, Zheng SL, Isaacs SD, et al (2003). Polymorphisms in the CYP1A1 gene are associated with prostate cancer risk. Int $J$ Cancer, 106, 375-8.

Cosma G, Crofts F, Taioli E, et al (1993). Relationship between genotype and function of the human CYP1A1 gene. J Toxicol Environ Health, 40, 309-16.

Crofts F, Taioli E, Trachman J, et al (1994). Functional significance of different human CYP1A1 genotypes. Carcinogenesis, 15, 2961-3.

Ding B, Sun W, Han S, et al (2018). Cytochrome P450 1A1 gene polymorphisms and cervical cancer risk: a systematic review and meta-analysis. Medicine, 97, e0210.

Ezzeldin N, El-Lebedy D, Darwish A, et al (2017). Genetic polymorphisms of human cytochrome P450 CYP1A1 in an Egyptian population and tobacco-induced lung cancer. Genes Environ, 39, 7-14.

Gajecka M, Rydzanicz M, Jaskula-Sztul R, et al (2005). CYP1A1, CYP2D6, CYP2E1, NAT2, GSTM1 and GSTT1 polymorphisms or their combinations are associated with the increased risk of the laryngeal squamous cell carcinoma. Mutat Res, 574, 112-23.

Gallegos-Arreola MP, Figuera-Villanueva LE, Troyo-Sanroman $\mathrm{R}$, et al (2008). CYP1A1 $* 2 \mathrm{~B}$ and $* 4$ polymorphisms are associated with lung cancer susceptibility in Mexican patients. Int J Biol Markers, 23, 24-30.

Garte S, Gaspari L, Alexandrie AK, et al (2001). Metabolic gene polymorphism frequencies in control populations. Cancer Epidemiol Biomarkers Prev, 10, 1239-48.

Gutman G, Morad T, Peleg B, et al (2009). CYP1A1 and CYP2D6 gene polymorphisms in Israeli Jewish women with cervical cancer. Int J Gynecol Cancer, 19, 1300-2.

Hirata H, Hinoda Y, Okayama N, et al (2008). CYP1A1, SULT1A1, and SULT1E1 polymorphisms are risk factors for endometrial cancer susceptibility. Cancer, 112, 1964-73.

$\mathrm{Hu}$ M, Zhou T, Pearlman AP, et al (2016). Comparative expression analysis of cytochrome P450 1A1, cytochrome P450 1B1 and nuclear receptors in the female genital and colorectal tissues of human and pigtailed macaque. $B A O J$ Pharm Sci, 2, 016.

Hussein AG, Pasha HF, El-Shahat HM, et al (2014). CYP1A1 gene polymorphisms and smoking status as modifier factors for lung cancer risk. Gene, 541, 26-30.

Jain V, Ratre YK, Amle D, et al (2017). Polymorphism of CYP1A1 gene variants rs4646903 and rs 1048943 relation to the incidence of cervical cancer in Chhattisgarh. Environ Toxicol Pharmacol, 52, 188-92.

Juárez-Cedillo T, Vallejo M, Fragoso JM, et al (2007). The risk of developing cervical cancer in Mexican women is associated to CYP1A1 MspI polymorphism. Eur J Cancer, 43, 1590-5.

$\mathrm{Li} \mathrm{S,} \mathrm{Li} \mathrm{G,} \mathrm{Kong} \mathrm{F,} \mathrm{et} \mathrm{al} \mathrm{(2016).} \mathrm{The} \mathrm{association} \mathrm{of} \mathrm{CYP1A1} \mathrm{gene}$ with cervical cancer and additional SNP-SNP interaction in Chinese women. J Clin Lab Anal, 30, 1220-5.

Li Y, Millikan RC, Bell DA, et al (2004). Cigarette smoking, cytochrome P4501A1 polymorphisms, and breast cancer among African-American and white women. Breast Cancer Res, 6, R460-73.

Little J, Sharp L, Masson LF, et al (2006). Colorectal cancer and genetic polymorphisms of CYP1A1, GSTM1 and GSTT1: a case-control study in the Grampian region of Scotland. Int J Cancer, 119, 2155-64.

Masson LF, Sharp L, Cotton SC, et al (2005). Cytochrome P-450 $1 \mathrm{~A} 1$ gene polymorphisms and risk of breast cancer: a huge review. Am J Epidemiol, 161, 901-15.

Melikian AA, Sun P, Prokopczyk B,et al (1999). Identification of benzo[a]pyrene metabolites in cervical mucus and DNA adducts in cervical tissues in humans by gas chromatography-mass spectrometry. Cancer Lett, 146, 127-34.

Meng FD, Ma P, Sui CG, et al (2015). Association between cytochrome P450 1A1 (CYP1A1) gene polymorphisms and the risk of renal cell carcinoma: a meta-analysis. Sci Rep, 5, 8108 .

Napoli N, Villareal DT, Mumm S, et al (2005). Effect of CYP1A1 gene polymorphisms on estrogen metabolism and bone density. J Bone Miner Res, 20, 232-9.

Natphopsuk S, Settheetham-Ishida W, Sinawat S, et al (2012). Risk factors for cervical cancer in northeastern Thailand: detailed analyses of sexual and smoking behavior. Asian Pac J Cancer Prev, 13, 5489-95.

Nebert DW, Dalton TP, Okey AB, et al (2004). Role of aryl hydrocarbon receptor-mediated induction of the CYP1 
enzymes in environmental toxicity and cancer. $J$ Biol Chem, 279, 23847-50.

Roszak A, Lianeri M, Sowińska A, et al (2014). CYP1A1 Ile462Val polymorphism as a risk factor in cervical cancer development in the Polish population. Mol Diagn Ther, 18, 445-50.

Rubin H (2001). Synergistic mechanisms in carcinogenesis by polycyclic aromatic hydrocarbons and by tobacco smoke: a bio-historical perspective with updates. Carcinogenesis, 22, 1903-30.

Santes-Palacios R, Ornelas-Ayala D, Cabañas N, et al (2016). Regulation of human Cytochrome P4501A1 (hCYP1A1): A plausible target for chemoprevention?. Biomed Res Int, 2016, 5341081.

Schlesselman JJ (1982). Case-control studies: design, conduct, analysis. Appendix A: case-control sample size. Oxford University Press, New York, pp 293-313.

Schwarz D, Kisselev P, Cascorbi I, et al (2001). Differential metabolism of benzo[a]pyrene and benzo[a]pyrene-7,8dihydrodiol by human CYP1A1 variants. Carcinogenesis, 22, 453-9.

Shah PP, Singh AP, Singh M, et al (2008). Interaction of cytochrome P4501A1 genotypes with other risk factors and susceptibility to lung cancer. Mutat Res, 639, 1-10.

Singh V, Rastogi N, Sinha A, et al (2007). A study on the association of cytochrome-P450 1A1 polymorphism and breast cancer risk in north Indian women. Breast Cancer Res Treat, 101, 73-81.

Siraj AK, Ibrahim M, Al-Rasheed M, et al (2008). Polymorphisms of selected xenobiotic genes contribute to the development of papillary thyroid cancer susceptibility in Middle Eastern population. BMC Med Genet, 9, 61-9.

Sugawara T, Nomura E, Sagawa T, et al (2003). CYP1A1 polymorphism and risk of gynecological malignancy in Japan. Int J Gynecol Cancer, 13, 785-90.

Tan YH, Sidik SM, Syed Husain SN, et al (2016). CYP1A1 MspI polymorphism and cervical carcinoma risk in the multi-ethnic population of Malaysia: a case-control study. Asian Pac J Cancer Prev, 17, 57-64.

Wang LN, Wang F, Liu J, et al (2017). CYP1A1 Ile462Val polymorphism is associated with cervical cancer risk in Caucasians not Asians: a meta-analysis. Front Physiol, 8, 1081.

Wright CM, Larsen JE, Colosimo ML, et al (2010). Genetic association study of CYP1A1 polymorphisms identifies risk haplotypes in nonsmall cell lung cancer. Eur Respir $J, 35,152-9$.

Wu B, Liu K, Huang H, et al (2013). MspI and Ile462Val polymorphisms in CYP1A1 and overall cancer risk: a metaanalysis. PLoS One, 8, e85166.

\section{@() $(0 \otimes$}

This work is licensed under a Creative Commons AttributionNon Commercial 4.0 International License. 